\title{
Learning while teaching: Student teachers' reflections on their teaching practicum
}

\author{
Dinçay Köksal $^{\text {a } * \text { (D) }}$, Gülten Genç ${ }^{\text {b }}$ \\ ${ }^{a}$ Çanakkale Onsekiz Mart University, Çanakkale, Turkeyy \\ ${ }^{b}$ İn̈̈nü University, Malatya, Turkey
}

APA Citation:

Köksal, D. Genç, G. (2019). Learning while teaching: Student teachers' reflections on their teaching practicum. Journal of Language and Linguistic Studies, 15(3), 895-913.

Submission Date: 02/26/2019

Acceptance Date: 08/18/2019

\begin{abstract}
Teaching practicum of English language teachers has been the heart of many studies in the recent years. However, most of those studies focused on the graduates of teacher training programs. In Turkey, graduates of English Language and Literature (ELL) departments are also qualified to be an English teacher as long as they have a teaching certificate awarded by a university after completing an intensive program called pedagogical formation. This study focused on the teacher candidates, who are graduates of ELL programs. More specifically, it aimed to investigate what those teacher candidates thought they learned through their intensive and short teaching practicum experience and the challenges they have met. For this purpose, the study adopted qualitative research methodology and 8 participants took part in the study. The data were collected via reflective journals and semi-structured questionnaires and were analyzed through thematic content analysis. Results indicated that student teachers' learning outcomes could be grouped under three themes such as pedagogical strategies, developing professional identity and developing positive feelings. The challenges could be grouped under four themes such as classroom management, time management, mixed-ability classes and difficulties in using technology. Based on the findings, some recommendations were offered.
\end{abstract}

(C) 2019 JLLS and the Authors - Published by JLLS.

Keywords: Pre-service teacher education; pedagogical formation; teaching practicum

\section{Introduction}

The teaching practicum has always been a crucial part of initial-teacher education programs. It also has a fundamental mission as preparing the prospective teachers for the world of teaching since those teacher candidates are mainly expected to be involved in a reciprocal interaction with the learners in the real classrooms during the practicum period. As suggested by Haigh, Ell and Mackisack, (2013, p.1) the success of a teaching practicum is one of the indicators of the success of teacher education programs. Although the importance of theoretical knowledge in teacher education is widely accepted, it has never been accepted adequate without the practical knowledge about teaching. For this reason, practice teaching has been integrated into all teacher training programs, to help the pre-service teachers to use their theoretical knowledge in the schools and classroom settings and to help them experience the real

\footnotetext{
${ }^{*}$ Corresponding author. Tel.: +0-286 2171303

E-mail address: koksal.dincay@gmail.com
} 
classroom atmosphere. Stevick (1980, p.4) remarks the importance of the teaching practicum by indicating that "success depends less on materials, techniques, and linguistic analyses, and more on what goes on inside and between the people in the classroom".

Practicum as a concept was defined as "teaching a class of foreign language learners and receiving feedback that the student teacher has a chance to apply knowledge and skills gained elsewhere or develop strategies for handling different dimensions of a language lesson" (Richards and Nunan; 1990, p.101). The definition puts an emphasis on the importance of developing strategies to cope with the multidimensional problems of a language class.

\subsection{Theoretical Background}

Many different labels such as "practice teaching, field experience, apprenticeship, practical experience, and internship" (Gebhard, 2009) are used to describe a "teaching practicum". Whatever it is called, a teaching practicum aims to provide student teachers the opportunity to become aware of practicing the theories, methods and techniques they studied along or in conjunction with the process of teacher education. Through this experience, student teachers will discern that they need to teach in entirely different ways from how they were once taught. In addition, they will realize that what they have learned at the desks of their faculty might not be in compliance with the reality of current classroom practice (Nguyen \& Baldauf, 2010). This is defined as 'reality shock' by Kramer (1974). It is used to describe the realization that school based knowledge is conflicted with the implementation at the workplace. In the context of this research, it implies a huge challenge experienced by pre-service teachers in putting the theory they grasped into practice in the real classroom during the teaching practicum. Therefore, it is not unusual to see prospective teachers with mixed feelings, confusion and under immense stress when they first visit their practice schools. It could be foreseen that they would be very enthusiastic and excited to be with the students in the real classrooms and would feel that their long-term dreams are about to come true. However, the fear of failure, possible problems related to the pupils, possible negative feelings towards any of the stakeholders might easily demotivate and cause tension in the teacher candidates (Hascher, Cocard and Moser, 2004).

The discussion about bridging the gap between theory and practice is not new and has always been a hot topic in the field of teacher education (Wallace, 1996; Farrell, 1998; Cheng et al., 2010; cited in Agudo). Many studies have been conducted and suggestions were proposed to improve the quality of teacher education to bridge the gap between theory and practice all over the world as presented in the literature review section. Wright (1990) recommended that the cooperation between theory and practice should be integrated into the teacher education programs from the very beginning since it is quite a challenging task. Cheng et al. (2010, p. 102) recommended that it should be the responsibility of teacher educators to raise the awareness of student teachers about the gap and then help them to cope with this hard process during the teacher education program. Disagreeing with Cheng (2010) and his colleagues, Hascher, et. al., (2004) claim that for student teachers, the best way to be competent in teaching and gain the necessary knowledge to be successful is to practice in the real classroom setting. Additionally, it should be noted that no matter how strong they are epistemological beliefs alone will never provide healthy learning environments.

According to Schön, (1987) practice is substantially a process of problem solving in its own right. Considering this idea, practitioners, namely, student teachers, are expected to solve the problems they encounter in the classroom using the theory they learned at the faculty. Observing the cooperating teacher as an expert will certainly give some clues to the student teachers about the ways of coping with the problems. 
Freeman (2011) emphasizes the importance of reflection claiming that student teachers must be supported to build the skills of reflectivity so that they can voice their experiences in teaching. Through thinking about their experiences or by watching their videotaped courses, they are expected to recognize dilemmas, assess the intended and unintended consequences of their teaching method and approach as well as accept their responsibility in the students' learning process.

\subsection{Literature Review}

It is possible to find many studies carried out with different stakeholders such as cooperating teachers, supervisors and student teachers and about different aspects of teaching practicum both in Turkey and abroad. All those studies are directly or indirectly related to the effectiveness of teaching practicum. Some of those studies are mentioned briefly in the following paragraphs focusing on reflections by teacher candidates.

A qualitative study was conducted by Payant and Murphy (2012) on the roles and responsibilities perceived by cooperating teachers at a university in the United States. The researchers reported some problems negatively affecting the practicum process due to difficulties in communicating with supervisors and unclear definitions of the mentors' roles and responsibilities. Another study was carried out by Koç (2012) with 358 cooperating teachers of distance ELT program. The results showed that mentors had a considerable need for preparation for their mentoring roles to provide adequate assistance to their teacher candidates. Mutlu (2014) also conducted a qualitative research with three cooperating teachers and the results were in line with Koç's (2012) study indicating that cooperating teachers experienced problems in providing efficient and constructivist feedback for student teachers and therefore they need guidance in this respect.

Beck and Kosnik (2002) conducted a mixed-methods research with 11 randomly selected student teachers at the University of Toronto in Canada. According to the results of the study, student teachers expected moral support from their cooperating teachers as well as being accepted as a professional teacher plus adequate quality feedback. Similar to the results of this research, in Tok and Y1lmaz (2011)'s study it was reported that student teachers complained about the biased and intolerant behaviors of their cooperative teachers as well as their indifference. They also added to their complaints that they were not treated like a teacher and forced to fulfill the cooperating teachers' personal daily tasks. In addition, they were not provided adequate feedback and support for their teaching. RakıcioğluSöylemez (2014) also reported that student teachers were not satisfied with the assistance provided by cooperating teachers in terms of "teaching strategies, problem-solving skills, new teaching ideas, and national English curriculum". Ekiz (2006) also made a contribution in a study conducted with 55 student teachers indicating lack of guidance and assistance from cooperative teachers. The result of the case study conducted by Yavuz (2011) with the six student teachers indicates the guidance provided by cooperating teachers was lacking. Similar to the results of aforementioned studies, the researcher reported that student teachers were mainly concerned about the mentor's failure in giving guidance and providing adequate feedback in the process. They also reported that guidance was perceived as a burden by cooperating teachers and they did not think that cooperating teachers were not eager to guide and help teacher candidates. The results of another study conducted by Coşkun (2013) seem to be in line with the results of Yavuz's study indicating cooperating teachers felt themselves under pressure because of being observed by the prospective teachers and they found it difficult to collaborate and establish an effective communication with student teachers.

Aydin (2016) investigated 194 student teachers of ELT departments from three different state universities. Contrary to these results of above-mentioned studies, the results revealed that although experiencing some problems student teachers were mainly satisfied with their cooperating teachers since 
they were protecting, supporting, and facilitating the process for prospective teachers and providing feedback for them. However, they were not fully satisfied with their roles of trainer-informant, assessorevaluator and collaborator. Sarıçoban (2010) conducted a research study to determine the problems experienced by student teachers during their practicum process and analyzed them under such categories as material based, curriculum based, student based, and classroom environment based. As can be seen from the review of the literature above, practicum systems, despite the differences in the ways of implementation in varied countries and schools are generally and indisputably approved of as a requirement to invest in pre-service teachers' development in terms of acquiring authentic experiences and building self-awareness (Haigh et al., 2013). So, this study intended to reflect the voices of student teachers from a state university in Turkey as a case of different implementation of teaching practicum.

\subsection{Context and Language Teacher Education in Turkey}

After the attempts of standardizing teacher education programs in Turkey in 1997 the theory and practice courses in the curriculum were inserted in a balanced way (Topkaya and Yalın, 2006; cited in Gürsoy, 2013) in all teacher education programs. The teaching practice courses, namely, School Experience and Practice Teaching, were offered during the seventh and eight semesters (Gürsoy, 2013). During the first semester student teachers are required to practice at schools for four hours a week within the content of the 'school experience' course which requires the pre-service teachers to observe the cooperating teachers while taking note of their techniques, materials and the general atmosphere in the school and classroom (YÖK, 2007). During the second term, the student teachers take the teaching practice course which includes visits schools for six hours a week plus more classroom experience where student teachers prepare weekly lesson plans, apply those lesson plans in the classrooms, while creating their portfolio (YÖK, 2007).

In 2007, some modifications in the curriculum of foreign language teacher training courses were made so that the teacher training curriculum involved more pedagogical courses rather than literature and linguistics. However, with the new regulations of Higher Education Council, in 2010 and 2011 "Pedagogical Formation Certificate Programmes", were established. They are with an 14 weeks intense programs of focused pedagogical courses. These courses are organized to qualify and prepare graduates of some related departments such as English Language and Literature as language teachers. In the literature, it has been seen that studies related to the student teachers' experiences of teaching practicum was mostly conducted with the graduates of teacher training programs. So, it is worth investigating and noting the experiences of teacher candidates who received professional knowledge and proficiency through intensive and shortened versions of the courses offered in the teacher training programs. In conclusion, the main aim of this study is to evaluate self-perceptions of student teachers with respect to their learning outcomes and challenges during their short intensive teaching practicum process.

\subsection{Research questions}

The research questions were formulated as follows;

1-What do student teachers think about the attainments they had through their teaching practicum?

2-How do student teachers feel about the challenges they have experienced? 


\section{Method}

\subsection{Design}

This is a qualitative phenomenological research. Phenomenological research designs tend to investigate the feelings, perceptions, judgments and beliefs of the participants about their own lived experiences (Patton 2002). Considering the scope of the study, a qualitative phenomenological research design was utilized to gain a more holistic and complete picture of the teaching practicum experienced by prospective English teachers.

\subsection{Setting}

In Turkey, in order to be an English teacher at the schools of the Ministry of Education, teachers have to be graduates of a teacher training program. However, to meet the demand for the English teachers in the country, graduates of English Language and Literature departments are also accepted to be qualified as English teachers as long as they have a teaching certificate awarded by universities after an intensive teacher training program called pedagogical formation. These programs provide the teacher candidates professional knowledge and proficiency (İnal, 2011) through short intensive versions (four weeks to 12 months) of the courses offered in the teacher training programs entitled "Introduction to Education," "Curriculum Development and Teaching," "Measurement and Evaluation," "Classroom Management," "Learning, Teaching Theories and Approaches", "Instructional Technologies and Material Design" and "Teaching Practice" (Durmaz and Yiğitoğlu, 2017). Contrary to aforementioned courses offered by English teacher training programs, students of ELL departments are offered intensive literature, linguistics and translation courses during their undergraduate education.

\subsection{Participants}

The participants of the study were chosen on the basis of convenience sampling. "The researcher uses convenience sampling to locate persons who are available who have already gone through or who have observed the process" (Richards and Morse, 2007; s.235). In the phenomenological research designs, identifying the most appropriate and accessible participant group has crucial importance since the focus is on the experiences of the participants and what they say about them. The research was conducted with 8 fourth year undergraduate prospective English teachers from the department of English Language and Literature (ELL) at a state university. They were enrolled in the university's pedagogical formation program in 2018-2019 academic year. They were all females and were supervised by one of the researchers during their teaching practicum.

\subsection{Data Collection}

Data for the research was collected through post-practicum, semi-structured questionnaires and reflective journals. The course of the pedagogical formation lasted 14 weeks and each week the participants and the researcher got together in the supervisor's office. In the course of the first week the participants were offered an introductory seminar about the process of the teaching practicum, by the supervisor. To help them write reflective journals, they were advised to focus on the following aspects: the methods they used in teaching; their strengths and weaknesses as a teacher; their observations about the classroom, school, students, and the cooperating teacher, as well as the challenges they met. After the visits to the schools started, each of the participants handed in their reflective journals and talked about their observations related to the school, classroom, students, and cooperating teachers. When they started to teach, they were also asked about their own teaching experiences about teaching and observations about teaching sessions of their friends. These sessions enabled transparency since each 
participant could easily make comments about each other. Through these discussion sessions, they provided constructive feedback for the other participants as well. In their reflective journals, student teachers were seen to mention the positive feedback they received from their peers and were able to make some adjustments in line with the suggestions of their peers. These sessions provided an additional perspective for the researcher and helped the process of coding and writing the themes for the research questions. Lastly, a semi-structured questionnaire was carried out after the course to see the evaluations of student teachers related to the process.

\subsection{Validity and Reliability}

The researchers worked together to ensure the validity and reliability of the research. For validity or credibility of the study, triangulation which suggests collecting the data from at least two different ways (Creswell, 2014, p.201) was applied. Brink (1993) suggests that in qualitative research, the researcher could increase the validity of the research by building "a trust-relationship with the subjects" (s: 36 ) and by spending time with them or coming together with the participants on several occasions. During the weekly meetings with the participants, the researcher tried to establish a reliable relationship with the participants by observing the discussions and giving constructive feedback to increase the validity of the research. At the last stage, the codes and the themes were reanalyzed by the second researcher to provide the "intercoder agreement" as suggested by Creswell (2014, p. 203). After determining the similarities and differences, an agreement was reached, and the validity of the research was ensured through the formula suggested by Miles \& Huberman (1994). The consistency between the encoders was calculated by using the formula (reliability: number of consensus / number of compromises + no compromise) proposed by Miles \& Huberman (1994) to determine the reliability of consistency between the encoders. The inter-coding compatibility was $0.95(0.9: 191 /(191+8)$. This shows that the consistency is sufficient and that the desired reliability is achieved.

\subsection{Data Analysis}

At the end of the course, all the forms and reflective journals were brought together to analyze the data manually through "Thematic Content Analysis" which was defined as "a process of working with raw data to identify and interpret key ideas or themes" (Matthews \& Ross, 2010). The data from each participant's reflective journals and answers to the questionnaire were considered as a whole to identify parallel or connected themes. After reading all the data twice, a list of codes as the basis of general themes was created by the researcher. These codes were used to create general themes in accordance with the research questions. The themes and codes emerged from the student teachers' journals and semi structured questionnaire forms. In the demonstration of data analysis, pseudonyms were used instead of the names the participants by the researchers. The questionnaire investigated different aspects of student teachers' learning outcomes and the challenges they met.

\section{Results}

In this section, the findings of the research based on the students' reflective journals and answers to the questionnaires will be discussed separately under the items listed as sub-problems of the research. Codes and themes related to the sub-problems within the scope of the research are shown in the table below. 


\subsection{What have student teachers learned through their teaching practicum}

After scanning the student teachers' reflective journals and answers to the semi-structured questionnaire meticulously with a focus on their attainments, 18 codes were generated and those codes were gathered under two themes as can be seen in the Table 1.

Table 1. Themes and Codes generated in relation to the student teachers' perception of their attainments during teaching practicum

\begin{tabular}{|c|c|c|}
\hline Research Question & Themes & $\begin{array}{l}\text { Codes from student teachers' } \\
\text { satatements }\end{array}$ \\
\hline \multirow[t]{3}{*}{$\begin{array}{l}\text { 1-What have student teachers } \\
\text { learned through their teaching } \\
\text { practicum? }\end{array}$} & $\begin{array}{l}\text { Student Teachers' Attainments in } \\
\text { relation to pedagogical strategies }\end{array}$ & $\begin{array}{l}\text {-Giving feedback } \\
\text {-Considering students' learning } \\
\text { styles } \\
\text {-Building up motivation } \\
\text {-Using positive reinforcement } \\
\text {-Encouraging learners } \\
\text {-Planning lessons } \\
\text {-Realizing interesting topics for the } \\
\text { learners (such as foreign culture) } \\
\text {-Realizing inadequacy in some } \\
\text { issues (preparing material, finding } \\
\text { different activities and games) }\end{array}$ \\
\hline & $\begin{array}{l}\text { Student Teachers' Attainments in } \\
\text { relation to developing professional } \\
\text { identity }\end{array}$ & $\begin{array}{l}\text {-Interacting with the experienced } \\
\text { teachers } \\
\text {-Spending time in the teachers' } \\
\text { lounge (drinking tea with them) } \\
\text {-Building confidence as a teacher } \\
\text { (acting like a teacher) } \\
\text {-Developing tolerance (towards the } \\
\text { learners) } \\
\text {-Being patient all the time } \\
\text {-Developing awareness about } \\
\text { teachers' roles in the classroom }\end{array}$ \\
\hline & Developing positive feelings & $\begin{array}{l}\text {-Coping with anxiety and stress } \\
\text {-Feeling that teaching is the right } \\
\text { profession for them } \\
\text {-Realizing that teaching is both } \\
\text { difficult and enjoyable } \\
\text {-Being happy to be with the } \\
\text { students in the classroom }\end{array}$ \\
\hline
\end{tabular}

\subsubsection{Theme 1: Student Teachers' Attainments in relation to pedagogical strategies}

In their reflective teaching journals and in the answers student teachers mentioned about many positive contributions of the teaching practicum. Examples of notes included being aware of explicit teaching like practices, setting learning goals and designing instructional materials in the classroom. Prospective teacher Sun, for instance, put "giving feedback" to the forefront in her experience indicating that she realized and observed the role and the power of feedback in the classroom. The teacher candidate Gül was impressed by the teacher who continuously provided oral feedback to the whole class not only to the student who made the error. Teacher Gül stated her thoughts in the following quotes; 
"While observing the class, I noticed that students often made many errors each time the teacher taught new things. At those moments, I was wondering why the students made so many errors even though they were just taught the subject. Learning new things is not easy of course and you become aware of this in the real classroom while teaching something new. My cooperating teacher was correcting the errors of each of the students even if the student was making the same error that his friend just made and was corrected a few minutes ago. The teacher was giving oral feedback all the time and she was explaining the subject again and again not only to the student who made the error but to the whole class. Sometimes she was repeating the sentence and was expecting the learners themselves to correct the errors but she was never ignoring any of the errors. I began to think that the teacher was using the pupils' errors as a kind of opportunity for consolidating and the teacher confirmed this later on during our post lesson discussion sessions".

It was noted that student teachers did not have admiration for the cooperating teachers all the time. They also reflected on some inadequacies in the classroom when relying on their theoretical knowledge. This might be seen as quite favorable on behalf of the efficiency of teaching experience. For instance, teacher Lale put emphasis on using different learning styles in the classroom in her reflection;

"In fact, not too many, but I can say there were a few students who were rather active and energetic in the classroom. They were constantly moving and getting things on the ground, moving back to the front in their desks, and moving their arms and legs all the time. They were not disturbing anyone but it was certain that they were not enjoying at all. While watching them, I thought that there was something missing in this class: Considering different learning styles and using them. I thought of sharing my opinion with my cooperating teacher but I didn't. I did not mean to be misunderstood by her".

Three of teacher candidates; Nergis, Yasemin and Nilüfer reported that they were inspired by the way that their cooperating teacher built up motivation, used various positive reinforcement strategies and encouraged the pupils. They reported that they were amazed to see how a short competition, applied by the teacher at the end of the lesson, activated and energized the pupils in the very few last minutes of the lesson. Nergis stated his astonishment in the following sentences;

"I could never imagine that students could be so enthusiastic and willing about a competition. The teacher was holding it in the last lesson of the week in each class. At the end of the course, they were often asked about the new language structures and new words, and even the reading and listening activities which were learned through that week. Usually the first finger lifters were given priority to reply and the teacher was scoring. The award was to be announced as the first, second and third winners of the week on the bulletin board of the class. They also were appreciated by the teacher and got a huge applause from their friends. All this was free but certainly worked as a real motivator".

Another striking contribution of teaching practicum process, according to teacher Gonca, is preparing effective lesson plans.

"During this time, each of us prepared lesson plans. In fact, we have examined and prepared many lesson plans in the faculty. To me, preparing a lesson plan here was very different. This time it was like writing a personal prescription. I mean, in the lesson plans at school we needed to consider many invisible things. For instance, I had to find some extra activities or materials for my lessons and allocate time for them in the lesson plans to make my job easier in the classroom. This experience taught me to prepare lesson plans special to the student. 
One student teacher wanted to draw our attention to another critical issue. Based on her in-class observations and her own experience of the lesson, teacher Menekşe, underlined that cultural issues and differences are of great interest to the students and therefore the use of materials that focus on cultural differences in foreign language education must be used. She added that;

"When I realized their interest in the differences of the societies I decided to use it in my own lecturing. So I compiled some information about the specific cultural features of the societies. First I gave examples and then asked them to compare with ours. We enjoyed a lot. They were sometimes surprised and sometimes laughed. For the following lessons one of the students shared some Japanese traditions and another one brought examples from ancient societies and it went on. It was a good opportunity for me to motivate them to actively participate in the lesson".

Teacher candidate, Fulya, handled the process with a critical eye on her own and she confessed that this process showed her how inadequate she was about reviving the lesson. She later added that that she needed to develop interesting materials, various activities and enjoyable games to attract the attention of students but she was rather inexperienced about that and decided to get help from her cooperative teacher.

\subsubsection{Theme 2: Student Teachers' Attainments in relation to developing professional identity}

Student teachers' reflections indicated that through the teaching practicum process, including observing the teachers and by spending time in the school with the other teachers they developed some professional attitudes in addition to developing some general professional skills. In this respect, one student teacher, Nilüfer noted the following;

"Not only was our cooperative teacher, but all the teachers in the school were pretty good to us. That's why I loved spending time at school. In our school there was one older teacher. When the teachers complained about the students in the break, she usually gave them some constructive advice. Despite her stern expression on her face, her patience and tolerance towards the students greatly impressed me".

Another notable experience was mentioned by teacher Lale. She reported the journey which made her feel like a real teacher went very well by stating that;

"When we first went to school, I was too shy to enter the teachers' room, sit with the teachers, and even drink tea. I've overcome it with the help and support of my cooperating teacher. I was really happy to come out of the class, go to the teachers' room and drink tea while listening to the teachers. I felt like a real teacher".

Some other crucial contributions of this process were helping the prospective teachers to develop self-confidence as a teacher and to develop awareness about teachers' roles in the classroom. Teacher Yasemin's observation was a good example for unveiling the professional identity of student teachers;

"My cooperating teacher and the other teachers at the school as well sometimes interfered with the students in the hall and warned them about some misbehavior. This was a good example of the teacher's task and responsibility which was not limited to class and teaching. All these have taught me to look at the students in the halls with a critical eye and kindly interfere if needed".

In addition to Yasemin's observation, teacher Gonca added some of her comments about difficult aspects of being a teacher.

"The school environment showed me that being a teacher really means being extremely patient and tolerant all the time. That's the hardest part, I think." 


\subsubsection{Theme 3: Developing positive feelings}

Student teachers come to the school setting with a set of beliefs, experiences and feelings either positive or negative. Those feelings are either reinforced or faded away during the teaching practicum. However, negative beliefs and feelings are expected to be replaced by more positive ones in this process. It was clear that the source of the students' anxiety was largely because they graduated from the Department of English Language and Literature. They were obviously feeling inadequate. However, the reflections of student teachers mostly indicated that they developed positive feelings and coped with their negative beliefs in this process. In this regard, Fulya brought up a very striking experience;

"My voice trembled in my first lesson. In fact, my friends said I stuttered. Of course the stress and anxiety weren't just my problem, we all had them. We were too anxious because, we weren 't trained as teachers at our faculties (English Language and Literature). However, over time, we all started to feel more comfortable. It was certainly a great help of the teachers at the school and our cooperating teacher".

The value of the teaching practicum process in easing the negative feelings of the student teachers were included in almost all the reflective journals. Student teacher Gonca's expressions were completely consistent with what teacher Fulya stated above;

"The first two or three weeks were real nightmares. Sometimes, I lost my sleep. My cooperating teacher was constantly tried to relieve me by reminding that this anxiety and stress would fade away in a few days, and that all the prospective teachers, even the graduates of teacher training programs, were experiencing the same thing. These were the things I actually knew, but it was important to hear them from my cooperative teacher".

Besides those negative feelings, reflective journals included many positive and enthusiastic utterances. What teacher Menekşe said was very remarkable in terms of building self-confidence during the practicum;

"While the students were trying to speak about cultural issues enthusiastically, actually, I was proud of myself for finding a topic that would entertain and activate them so much. So I told myself that teaching is the right job for me. I started to believe that I would be a good teacher although I was a graduate of English Language and Literature department".

Sometimes, student teachers were seen to have mixed feelings. Teacher Gül, for instance, put an emphasis on both the difficult and enjoyable aspects of teaching. She added that despite all the difficulties, she felt happy being with the pupils in the classroom.

\subsection{What are the challenges they have experienced?}

After reading the student teachers' reflective journals and answers to the semi-structured questionnaire focusing on the challenges they experienced, 14 codes were generated and those codes were gathered under four themes as can be seen in the Table 2 .

Table 2. Themes and Codes generated in relation to the student teachers' perception of the challenges experienced during teaching practicum

\begin{tabular}{|l|l|l|}
\hline \multicolumn{1}{|c|}{ Research Question } & \multicolumn{1}{|c|}{ Themes } & \multicolumn{1}{c|}{$\begin{array}{c}\text { Codes from student teachers' } \\
\text { statements }\end{array}$} \\
\hline $\begin{array}{l}\text { 2-What are the challenges they } \\
\text { have experienced? }\end{array}$ & $\begin{array}{l}\text { Challenges experienced by student } \\
\text { teachers' in relation to classroom } \\
\text { management }\end{array}$ & $\begin{array}{l}\text {-Keeping the classroom quiet } \\
\text {-Keeping the learners on task } \\
\text {-Dealing with reluctant learners } \\
\text {-Involving all the learners in the } \\
\text { activities } \\
\text {-Crowded classrooms }\end{array}$ \\
\hline
\end{tabular}




\begin{tabular}{|l|l|l|}
\hline & & $\begin{array}{l}\text {-Disruptive behaviors } \\
\text {-Students constantly asking } \\
\text { irrelevant questions } \\
\text {-Talkative students }\end{array}$ \\
\hline & $\begin{array}{l}\text { Challenges experienced by student } \\
\text { teachers in relation to time } \\
\text { management }\end{array}$ & $\begin{array}{l}\text {-Lack of time } \\
- \text {-Too much things to in a very } \\
\text { short time }\end{array}$ \\
\hline & $\begin{array}{l}\text { Challenges experienced by student } \\
\text { teachers' in relation to mixed } \\
\text { ability classes }\end{array}$ & $\begin{array}{l}\text {-Students with very low and } \\
\text { average levels in the same } \\
\text { llassroom and } \\
\text {-Indifferent learners and } \\
\text { enthusiastic ones are sharing the } \\
\text { same desk }\end{array}$ \\
\hline & $\begin{array}{l}\text { Challenges experienced by student } \\
\text { teachers' in relation to difficulties } \\
\text { in using technology }\end{array}$ & $\begin{array}{l}\text {-Inability in using smart boards } \\
\text {-Getting stressed while adjusting } \\
\text { the smart board each time. }\end{array}$ \\
\hline
\end{tabular}

\subsubsection{Theme 1: Challenges experienced by student teachers' in relation to classroom management}

One of the challenges experienced by almost all the student teachers, according to their reflections, was dealing with a crowded classroom. Student teachers reported that the other challenges were all caused by crowding too many students into one room. Teacher Nergis, explained it in her following sentences;

"The problem that pushed me the most in the class was talkative students who were constantly speaking. In addition, there was a constant gabble that really bothered me. I looked at their eyes to imply them to be quiet, but that didn't work. I had to warn the same students many times. It would certainly be easier to control if the class was not so crowded".

Teacher Nilüfer complained that she could not even start teaching due to the noise in the classroom and the cooperating teacher had to keep the silence in the class and interfere in the process many times during her teaching. Teacher Lale brought up two difficulties she had:

"It was really annoying and I could not know what to do. We were doing a listening activity and the text was relatively a long one. Only a few of the students could sit in silence and listen to the whole text. I felt desperate".

She did not know how to keep the learners on task until the end of the activity. Indicating another problem teacher Gül uttered that it was highly difficult to involve some of the pupils in the lesson. Whatever the activity and the subject was they were indifferent and were reluctant to reply any of the questions. Teacher Gül did not think that the problem as unique to her and added;

"Those students were discouraging of course and affected the flow of lessons negatively while some of my friends were lecturing. Some of them were constantly asking irrelevant questions and laughing, for example. Actually, I completely ignored them and enjoyed the lesson with the volunteer ones, because they were always the same students who were reluctant, naughty or on their own even in their regular lessons with the cooperating teacher".

\subsubsection{Theme 2: Challenges experienced by student teachers' in relation to time management}

Lack of time and the inability of inexperienced student teachersto plan the length of lessons were reflected by all eight candidates. All of them had difficulty in using time effectively and finishing the lesson as previously planned. Student teachers Gonca and Yasemin complained that there were always too many things to do in the course of a lesson. Gonca indicated that she failed in being in line with the plans in her following expressions; 
"The problem was that everything was not running as planned. The time we thought to be sufficient was never enough. The students were continuously asking questions and something distracting was happening in each lesson".

\subsubsection{Theme 3: Challenges experienced by student teachers' in relation to mixed ability classes}

By mentioning the problems of mixed-ability classes, student teachers reported one of the most frequently experienced problems in language classes. In a government school, students are not expected to be grouped according to their proficiency level in the foreign language. In their reflective journals, all the student teachers mentioned the variety of language ability among the pupils, in terms of their language proficiency and interest. One student teacher, Gül, drew attention to this point by saying;

"It's really hard to be a perfect teacher even if you want. Even if you plan everything, you can't interfere in some things. Some students are at the level that they should really be in that class, whereas others can be at a level that should never be there".

Student teachers, however, did not seem to solve those problems. They also did not suggest any possible solutions for the problems they perceived. They looked to accept the situation as it was hopeless. Teacher Nergis, mentioned the similar problems without suggesting a solution to the problem. She added that;

"Some students were quite hard-working and were really trying to be successful. But his friend sitting in the same desk right next to her was so indifferent and reluctant to ask why he should learn English. It is unfair to ask them to work together for hardworking student, I think".

\subsubsection{Theme 4: Challenges experienced by student teachers' in relation to difficulties in using technology}

In using technology, student teachers found themselves quite inadequate. Actually, according to the reports of student teachers, the only technological equipment in the classroom was the smart board and the cooperative teacher was pretty skillful in using it. Teacher, Nilüfer, reported that she got stressed in the classroom in each time she was lecturing due to the smart board. Teacher Menekşe summarized the difficulty she had in her following expressions;

"I didn't know I was so awkward in using technology. We wasted some time in adjusting the smartboard."

\section{Discusion}

The study referred to the social learning theory as a theoretical framework to have a detailed understanding of the attainments and challenges experienced by student teachers over the complete practicum process. Being in line with the previous studies (Orland-Barak and Yinon, 2007; ), the findings of the study emphasized once more the effectiveness of a teaching practicum in terms of developing pedagogical strategies, teacher identity and positive feelings towards teaching. The study revealed that teaching experiences during the practicum process brought awareness to the student teachers about their own strengths and weaknesses of teaching. It also caused a change in their beliefs and attitudes towards their capabilities. As supported by Tomlinson, (1995), when student teachers came to their practice schools they had their habits, values, emotions and attitudes about teaching. It would be awkward to expect their mind to be a "tabula rasa" for teaching as suggested by Watson (1913). As social agents, they tend to bring the sociocultural realities and experiences related to teaching and learning process to the pedagogical setting. However, the expectation from the practicum was to raise the awareness of student teachers about their strengths and weaknesses in teaching. For instance, the 
present research indicated that student teachers had the belief that they did not possess the necessary knowledge and skills for teaching since they were graduates of an English Language and Literature program. However, in their post practicum reports they looked to gain self-confidence and to believe that they could develop the required skills and knowledge for teaching in this intensive teacher preparation program.

According to Vgotsky's (1978), social interaction theory, learning takes place through interactions with the nature, things and people around, both through actions and through language. Student teachers' reports indicated that by observing classroom, interacting with the learners in the classroom and with the cooperative teacher through pre and post discussion sessions they gained some pedagogical strategies to allow them to manage the instructional processes. Welcoming students' errors and using them as opportunities to consolidate the newly learned knowledge and practice, applying different learning styles, finding ways to enhance motivation, providing some kind of reinforcement, encouraging learners to participate in the activities, planning effective lessons, diagnosing students' interest and realizing their weaknesses were among the pedagogical strategies gained by student teachers through this process. This finding supports the existing literature on the contribution of teaching practicums on the professional development process of student teachers. (Goodnough et al. (2009), conducted a fieldbased study investigating the teaching practicum process and suggested that the process enabled preservice teachers to develop new knowledge and skills by integrating theory and practice. Similarly, Gan and Lee (2015), in their study, proved that practice teaching provided student teachers important opportunities to develop knowledge and skills in real classroom settings as well as deciding what to teach and how to teach it.

When the narrated reports were read, student teachers were seen to develop a sense of belonging to the teaching profession over practicum process. Professional identity might be formed through everyday practice in various contexts (Dillabough, 1999). Huizen et. al.(2005) also claimed that the professional identity could best be developed through the teaching practicum process, from the Vygostkian standpoint. Practicing teaching in the authentic classroom setting and interacting with real students allowed the student teachers to perceive themselves as teachers. The reasons for the change in the selfperception of student teachers were mainly interacting with the experienced teachers, building confidence as a teacher (acting like a teacher), developing tolerance and patience towards learners and being aware of teachers' roles in the classroom. In the existing literature teachers' professional identity was investigated under three groups. The first group, the teacher is seen as a subject matter expert providing the knowledge and skill in the subject. In the second group the teacher is the pedagogical expert supporting pupils' development socially, emotionally, and morally. In the third and last group the teacher is seen as a didactical expert evaluating instructional processes (Atkinson, Smith and Hildegard, 1987, p. 750). In the narratives of student teachers, it was seen that student teachers felt themselves efficient as a subject matter provider and readily embraced the professional identity. Moreover, by becoming aware of their roles at school and in the classroom and interacting with teachers and pupils student teachers felt themselves as pedagogical experts which would eventually lead them to develop their own professional identity. Lastly, it should be added that student teachers were aware that teaching as a profession required more than being an expert at the subject matter. It could be seen in the reflective journals involving student teachers' emphasis on developing tolerance and patience towards learners all the time to support pupils socially and emotionally, as a pedagogical expert.

The experience of the teaching practicum enabled the student teachers to develop positive feelings and attitudes towards teaching and cope with the anxiety and stress they had before starting the process. Previous studies also reported that prospective teachers experienced anxiety and stress due to mentors, supervisors, methods and materials plus classroom management issues before they started their teaching experience (Paker, 2011). Student teachers reflected that through the constructive feedback they got 
from their friends and cooperating teachers and establishing positive relationship with students, they could overcome their anxiety and stress. Similar result was yielded in Yangın-Ekşi and Yakışık's (2016) study. Furthermore, student teachers experienced mixed feelings after recognizing some challenges but still reported they enjoyed teaching. Student teachers' happiness and satisfaction with teaching bring to mind the possible and desired success of those future teachers. Hereby, student teachers put emphasis on the importance of peer feedback in developing positive feelings. Student teachers supported each other in this process by empathizing and providing supportive feedback for each other.

In addition to these points, another striking and pleasing finding of the research was about the constructive behaviors of both the cooperating teachers and teachers at the school. Although it was beyond the scope of this research, student teachers in their reflections, very often referred to the wide support and guidance of cooperating teachers in coping with negative feelings and anxiety. So, it is worth adding that important role of the attitudes and behaviors of cooperative teachers in the success of the practicum process could not be ignored. Ralph et. al. (2007) also reported that establishing good relationship with the school staff was the key to a successful and motivating practicum.

Besides the attainments, student teachers gained through the teaching practicum they also experienced and reported many challenges that they had to deal with. The primary challenges were related to classroom management issues. They reported serious difficulties in keeping the classroom quiet and on task. Dealing with reluctant learners and their disruptive behaviors were also among the challenges reported by the student teachers. One more major concern reported by the student teachers was managing time and being able to finish the lesson as it was planned. What was common in all their reports and reflections was disappointment in terms of classroom and time management. Other unexpected problems revealing the student teachers that in the real classrooms everything did not go as smoothly as pre-planned, were the challenges of dealing with mixed ability learners and using technology properly. Even though once they were the parts of those classrooms, student teachers found the students in varying levels of proficiency and enthusiasm in the same classroom and at the same desk quite surprising. One student teacher reported that she developed strategy such as finding interesting topics for learners to overcome those problems while another one expressed that she ignored the students causing problems and held the lesson just with the active participants. However, what the other learners did to overcome those challenges is in the dark since they did not mention it and just seemed to accept them.

All these disappointment and frustration reflected by student teachers were clearly the result of "reality shock" (Kramer, 1974) and they felt it when they lectured in the authentic classroom atmosphere. It might be seen as a kind of adaptation to the new role of teaching, professional growth and development by realizing the difference between theory and practice. In a sense, Ur's (1992) 'learnthe-theory-and then-apply-it' model did not come true once more in this research as also suggested by Seferoğlu, (2007). The theory-based education alone did not seem to be adequate enough to equip the student teachers to meet the demands of school realities. However, it is this process which moves student teachers beyond their understanding of the instructional processes.

The study conducted by Mirici and Ölmez-Çağlar (2017) with non-ELT department graduates reached the similar result with the present study and suggested that graduates of non-ELT departments needed more practicum opportunities. As a result, as they gain experience in practice over time, they are expected to act differently and develop strategies to overcome the challenges.

\section{Conclusion and Implications}


One of the major concerns of the educators and policy makers all over the world in this millennium is training qualified teachers. As a result of this research, teacher candidates are required to practice teaching in real schools during their teacher training programs. Through this research, the researchers tended to investigate the perceptions and feelings of teacher candidates about the attainments and challenges they experienced in this process. By using the student teachers' reflective journals and questionnaires they were given the opportunity to express their feelings beyond superficial responses and become aware of their teaching process with all its strengths and weaknesses.

The conclusions of the study should be underscored in many respects. Firstly, the practicum process raised the awareness of student teachers about their strengths and weaknesses. Through in-class observations and post lecturing discussion sessions with the cooperating teacher they made progress in favor of their instructional skills. In addition, student teachers could develop a professional identity through this process by interacting with the students and staff at schools. They experienced a transition in their self-perception from being a student to being a teacher. Furthermore, duringthe teaching practicum student teachers developed positive feelings and with the support of cooperative teachers and their friends they learned to overcome their anxiety and stress. Secondly, student teachers confronted the realities of the work place, namely the classroom and realized their inadequacies.

The findings have implications for the teaching practicum processes particularly for the programmes called pedagogical formation. Additionally, they have some recommendations for universities and policy makers about the need to enhance the professional knowledge and proficiency of the graduates of "ELL" departments since these students may also be qualified as teachers. It seems that effort to train them through those intensive and shortened versions of the teacher training programs seems to be inadequate in many respects. It is highly recommended to equip those teacher candidates with a more comprehensive and intensive teacher education process instead of the currently fragmented process. It was concluded that those student teachers did not feel themselves inadequate in subject matter but they still had high anxiety since they were not trained as teachers and reported a lack of self-confidence. To avoid the disadvantages of this short term teacher training programs, in other words, "fast-track-training model" as suggested by Castle at al. (2006), more time should be allocated for teaching practicum to give the opportunity of spending more time in the school context. It should be borne in mind that despite the challenges the teaching practicum causes, the whole process is quite instructive in many respects and considerably contribute to the process of professional development. Thus, the length of a teaching practicum should be recommended to increase. In addition, some teacher training courses could be offered as elective courses to the students of ELL department along with their training at the faculty. It is also recommended to replicate the studies with the graduates of teacher training programmes and comparative studies with both groups.

The study certainly has some limitations to be acknowledged. Obviously, the results of the study may not be generalized due to the method preferred in the research. However, the study's main aim was to get in depth understanding of the situation rather than generalizing the results.

\section{References}

Agudo, J.M.Z. (2016). What Type of Feedback do Student Teachers Expect from their School Mentors during Practicum Experience? The Case of Spanish EFL Student Teachers, Australian Journal of Teacher Education, 41 (5), 36-51.

Atkinson, R. L., Atkinson, R. C., Smith, E. E., Hilgard, E. R. (1987). Introduction to psychology (9th ed.). San Diego, New York: Harcourt Brace Javanovich Publishers. 
Aydın, Ö. (2016) An Exploration on mentoring process in ELT practicum: Perspectives of student teachers, cooperating teachers, and supervisors. Unpublished Master's Thesis. METU, Ankara, Turkey

Beck, C., Kosnik, C. (2002). Components of a Good Practicum Placement: Pre-Service Teacher Perceptions. Teacher Education Quarterly, 29, 81-98.

Brink, H.I.L. (1993) Validity and relability in qualitative research. Paper delivered at SA Society of Nurse Researchers' Workshop-RAU 16(2)

May M.H. Cheng, Annie Y.N. Cheng, Sylvia Y.F. Tang (2010) Closing the gap between the theory and practice of teaching: implications for teacher education programmes in Hong

Kong, Journal of Education for Teaching, 36(1), 91-104

Castle, S., Fox, R. K., Souder, K. (2006). Do professional development schools (PDSs) make a difference? A comparative study of PDS and non-PDS teacher candidates. Journal of Teacher Education, 57 (1), 65-80

Creswell, J. W. (2014). Research Design: Qualitative, Quantitative and Mixed Methods Approaches (4th ed.). London: Sage Publications Ltd.

Coşkun, A. (2013). Stress in English language teaching practicum: the views of all stakeholders. Hacettepe University Journal of Education, 28(3), 97-110.

Dillabough, JA (1999). Gender Politics and Conceptions of the modern teacher: Women, identity and professionalism. British Journal of Sociology of Education, 20 (3), 373-394.

Durmaz, M., Yiğitoğlu, N. (2017). Factors in the professional identity development of alternatively certified English languages teachers (ACELTs). International Online Journal of Education and Teaching (IOJET), 4(4), 398-416.

Ekiz, D. (2006). Mentoring primary school student teachers in Turkey: Seeing it from the perspectives of student teachers and mentors. International Education Journal, 7(7), 924-934.

Gan, Z., Lee, F.K.J. (2015). Understanding ESL student teachers' learning of classroom

practices in the practicum: a case study in Hong Kong. The Asia-Pacific Education Researcher. 25 (2), 251-266.

Gebhard, J.G.(2009). The Practicum. In Burns A. \& J.C.Richards (eds.) The Cambridge Guide to Second Language Teacher Education. Cambridge: CUP.

Goodnough, K., Osmond, P.,Dibbon, D., Glassman, M., Stevens, K. (2009). Exploring a triad model of student teaching: Pre-service teacher and cooperating teacher perceptions, Teaching and Teacher Education, 25 (2) 285-296.

Gürsoy, E. (2013) Improving practicum for a better teacher training. Procedia-Social and Behavioral Sciences 93, 420-425.

Hascher, T., Cocard, Y., Moser, P. (2004). Forget about theory-practice is all? Student teachers' learning in practicum. Teachers and Teaching: Theory and Practice, 10, 623-637.

Haigh, M., Ell, F., Mackisack, V. (2013). Judging teacher candidates' readiness to teach. Teaching 
and Teacher Education, 34, 1-11.

Higher Education Council. (2007). Teacher preparation and faculty of education (1998-2007). Ankara, Turkey: www.yok.gov.tr/component/option,com_doc/

Huizen, P. V., Oers, B.V., Wubbels, T. (2005) A Vygotskian perspective on teacher education. Curriculum Studies, 37 (3) 267-290

İnal, K. (2011). Pedagojik sertifikasyon programı. Akademik Bülten, 9(1), 17-24. Retrieved from: http://gaziuniversiteli.org. Retrieved on: 06.02.2019

Koç, E. M. (2012). Idiographic roles of cooperating teachers as mentors in pre-service distance teacher education. Teaching and Teacher Education: An International Journal of Research and Studies, $28(6), 818-826$.

Kramer M. (1974) Reality Shock: Why Nurses Leave Nursing. C.V. Mosby Company, St Louis Larsen - Freeman, D. Marti Anderson. (2011). Techniques and Principles in Language Teaching. Oxford: Oxford University Press.

Matthews, B. and Ross, L. (2010) Research Methods. Pearson Longman, London.

Miles, M, B., Huberman, A. M. (1994). Qualitative data analysis: An expanded Sourcebook. (2nd ed). Thousand Oaks, CA: Sage

Mirici, İ. H., Ölmez-Çağlar, F. (2017). Reflections on practicum experiences of non-ELT student teachers in Turkey, ELT Research Journal, 6(3), 276-292

Mutlu, G. (2014). Challenges in practicum: pre-service and cooperating teachers' voices. Journal of Education and Practice. 36(5), 1-7.

Nunan, D., J. C. Richards (eds.) (2015). Language learning beyond the classroom. London: Routledge.

Nguyen, H. T. M, Baldauf Jr. R. B. (2010) Effective Peer Mentoring for EFL Pre-service Teachers' Instructional Practicum Practice, The Asian EFL Journal Quarterly, 12(13); 40-61

Orland-Barak, L. Yinon, H. (2007) When theory meets practice: What student teachers learn from guided reflection on their own classroom discourse. Teaching and Teacher Education, 23, 957-969

Patton, M. Q. (2002). Qualitative research and evaluation methods. Thousand Oaks, CA: Sage.

Paker, T. (2011). Student teacher anxiety related to the teaching practicum, Eurasian Journal of Educational Research, 42, 207-224.

Payant, C., Murphy, J. (2012). Cooperating teachers' roles and responsibilities in an MATESOL practicum. TESL Canada Journal, 29(2), 1-23

Rakicioglu-Soylemez, A., Eroz-Tuga, B. (2014) Mentoring expectations and experiences of prospective and cooperating teachers during practice teaching. Australian Journal of Teacher Education, 39, (10), 146-168.

Ralph, E., Walker, K., Wimmer, R. (2007b). The practicum in professional education: Pre-service students' experiences. Transformative Dialogues, 1(2), 1-17.

Richards, L. and Morse, J.M. (2007) Readme First for a User's Guide to Qualitative

Methods. 
Sage Publications, Thousand Oaks.

Richards, J.C, Nunan, D (1990). Second language teacher education. Cambridge, $\quad$ England: Cambridge University Press.

Sarıçoban, A. (2010). Problems encountered by student-teachers during their practicum studies. Procedia-Social and Behavioral Sciences, 2(2), 707-711.

Schön, D. (1987). Educating the reflective practitioner. San Francisco: Jossey-Bass

Seferoğlu, G. (2006). Teacher candidates' reflections on some components of pre-service English teacher education programme in Turkey. Journal of Education for Teaching, 32(4), 369-378.

Stevick, E.W. (1980). Teaching languages: A way and ways. Rowley, Mass: Newbury House.

Tok, H., Y1lmaz, M. (2011). Student teachers' perceptions about mentor teachers: a case study in Turkey. Journal of Social Sciences, 4(2), 101-108.

Tomlinson, P. (1995) Understanding mentoring: reflective strategies for schoolbased teacher preparation. Buckingham \& Philadelphia: Open University Press.

Ur, P. (1992). Teacher learning. ELT Journal 46 (1): 56-61.

Vygotsky, L.S. 1978. Mind in society; The development of higher mental processes. Translated and edited by (M. Cole, V. John-Steiner, S. Scribner, and Souberman. Cambridge, MA: Harvard University Press.

Watson, J. B. (1913). Psychology as the behaviorist views it. Psychological Review, 20(2), 177. Available at: http://dx.doi.org/10.1037/h0074428

Wright, T. (1990). Understanding classroom role relationships. In J. C. Richards, \& D. Nunan (eds.), Second language teacher education (pp.82-97). Cambridge: Cambridge University Press

Yangın Ekşi, G., Yılmaz-Yakışık, B. (2016). To be anxious or not: Student teachers in the practicum. Universal Journal of Educational Research, 4(6), 1332-1339.

Yavuz, A. (2011). The problematic context of mentoring: evidence from an English language teaching department at a Turkish university. European Journal of Teacher Education, 34(1), 43-59 


\section{Öğretirken öğrenme: Öğretmen adaylarının öğretmenlik uygulamasına ilişkin görüşleri}

\section{$\ddot{O} \mathbf{z}$}

Öğretmenlik uygulaması son yıllarda birçok çalışmanın odağında yer almıştır. Bununla birlikte, bu çalışmaların çoğu Eğitim Fakültesi öğrencileriyle gerçekleştirilmiştir. Türkiye'de, İngiliz Dili ve Edebiyatı (ELL) bölümü mezunları, Eğitim Fakültesi öğretim üyeleri tarafından verilen kısa ve yoğun bir programın ardından öğretim sertifikasına sahip olurlar ve İngilizce öğretmeni olmaya hak kazanırlar. Bu çalışma ise ELL programlarından mezun olan öğretmen adayları ile gerçekleştirilmiştir. Başka bir ifadeyle, öğretmen adaylarının yoğun ve kısa öğretim uygulaması sırasında edindikleri kazanımlar ve karşılaştıkları zorluklara ilişsin düşüncelerini derinlemesine araştırmayı amaçlamıştır. Bu amaçla, araştırma nitel araştırma deseniyle gerçekleştirilmiştir. Çalışmaya 8 katıılımcı katılmıştır. Veriler, öğretmen adaylarının günlükleri ve yarı yapılandırılmıs anketler aracılığıyla toplanmıș ve tematik içerik analizi ile analiz edilmiştir. Sonuçlara göre, öğretmen adaylarının kazanımları; pedagojik stratejiler edinme, öğretmenlik kimliği oluşturma ve olumlu duygular geliştirme gibi üç ana başlık altında toplandığını, yaşadıkları zorluklar da sınıf yönetimi, zaman yönetimi ve farklı yetenekli öğrencilerin olduğu sınıflarda öğretim yapmak ve teknoloji kullanmak gibi dört başlık altında toplanmıştır.

Bulgulara dayanarak bazı önerilerde bulunulmuştur.

Anahtar Sözcükler: Öğretmen yetiştirme; pedagojik formasyon eğitimi; öğretmenlik uygulaması

\section{AUTHOR BIODATA}

Prof. Dr. Dinçay Köksal is currently a faculty member in the Department of Foreign Language Education at Çanakkale Onsekiz Mart University. He has taught such courses as 'Translation', 'Testing and Evaluation in English Language Education', 'Teaching English/Foreign Language to Young Learners' in B.A and M.A programmes 'Philosophy of Educational Research' in PhD programme. He founded Foreign Language Education Research and Practice Center in that university in 1996. He organised many international conferences International ELT Research Conferences. He also founded some associations - NGOs concerning language education and education research in general - UDEAD, ULEAD and EAB (Educational Research Association) in Turkey in 2008. He coordinated one EU lingua project locally as a partner called 'European Awareness and Intercomprehension'. He was the local coordinator of another project called 'Redinter'. He has many articles published in journals and papers presented at international conferences and congresses. He is the author of a book on teaching translation, and co-author of a book on Intercultural Communication and the editor of two books.

Dr. Gülten Genç is currently a faculty member in the Department of Foreign Language Education at İnönü University. The courses she has taught include Teaching English to Young Learners, Approaches to ELT and Second Language Acquisition. She has been involved in the organization of several conferences, workshops and seminars. Her research interests include second/foreign language teaching methodology, intercultural communication, foreign language teaching methodology and language teacher education. 